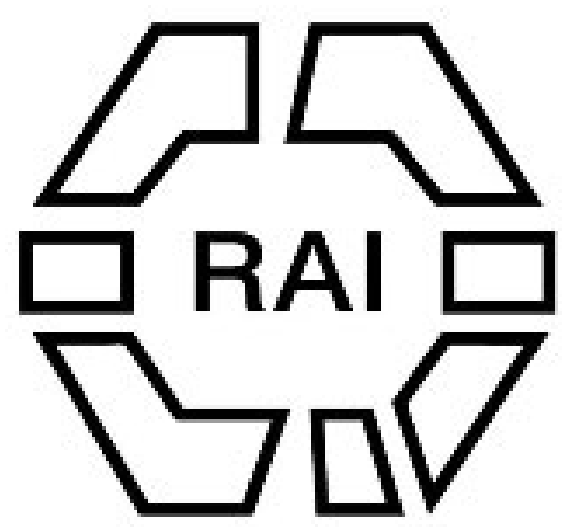

On Certain Rude Implements from the North Downs

Author(s): B. Harrison

Source: The Tournal of the Anthropological Institute of Great Britain and Ireland, Vol. 21 (1892), pp. 263-267

Published by: Royal Anthropological Institute of Great Britain and Ireland

Stable URL: http://www.jstor.org/stable/2842552

Accessed: 16/06/2014 01:57

Your use of the JSTOR archive indicates your acceptance of the Terms \& Conditions of Use, available at http://www.jstor.org/page/info/about/policies/terms.jsp

JSTOR is a not-for-profit service that helps scholars, researchers, and students discover, use, and build upon a wide range of content in a trusted digital archive. We use information technology and tools to increase productivity and facilitate new forms of scholarship. For more information about JSTOR, please contact support@jstor.org. 


\section{On certain Rude Implements from the NoRTh Downs.}

\section{By B. Harrison, Esq.}

Professor Prestwich having suggested I should make some remarks on the series of rude implements from the chalk plateau, I will briefly do so.

For many years I have been a diligent and successful hunter of palæolithic implements in the Shode Valley around my home at Ightham, and being familiar with the older forms, I was much impressed with the Currie Wood specimen when seen in Dr. Evans' collection in 1883.

Having made many excursions across the Cray Basin from Holwood, by Down Cudham and Currie Wood, I was well acquainted with the locality, and the question was put to myself, why should not similar specimens be found on the chalk plateau above Ightham? which to me seemed to present similar features.

For this purpose I instituted a rigorous search on the capping of Tertiaries lying just north of Ash Church.

Success, however, did not attend my first efforts, and it was not until the 19 th of November, 1885, that a rich brown ochreous implement was secured.

This seemed to me the equivalent of the Currie Wood find, and somewhat like it, and I forwarded it to Dr. Evans, who in a few days replied with the comforting and encouraging remark: "The specimen you sent me from Ash much resembles in character and material the Currie Wood implement."

I was also encouraged to persevere by Professor Prestwich, to whom I sent all my successive finds, and advised with me as to the grounds to search.

This stimulated me to continue the work, but as the locality is distant about six miles, and my time is much occupied, a passing glance only cuuld be bestowed for some months.

However, on each occasion on which I visited it, some relic of palæolithic age was secured, though I must own they were of so fragmentary and rude a character it needed the trained eye of a specialist to refigure.

On my submitting these fragments to Dr. Evans previous to the Ightham paper being given by Professor Prestwich, all were accepted, and I felt very desirous to thoroughly and rigorously search the area inch by inch.

Some time elapsed ere this could be done, as one part of the coveted area was a mass of weeds, and the next patch in corn; 
but as soon as available for search, a day was devoted to the few acres, and about a dozen implements found.

Being much impressed with some rudely worked ochreous flints thus secured, I was prompted to search diligently on a patch of deep-stained much worn ochreous gravel lying by South Ash Farm, with which I had been familiar for many years.

On this spread stones apparently bearing work had been noticed, and eventually it dawned upon my mind that these rude and misshapen flints might possibly represent an earlier layer of palæolithic life-or at least might be rude field tools, which had hitherto been slighted and overlooked by those workers who had only sought for more highly finished specimens.

Feeling confident, I kept on with a determination to prove this point if possible.

Many and frequent visits were made to obtain specimens, and so many were acquired that I felt desirous to extend my knowledge of the area, and for this purpose traced from near the escarpment to a field near West Yoke, patches of deep-stained ochreous flint.

Similar observations were made by tracing along the ridge from Bower Farm, Eynesford, to Romney Street, and here, too, I was fortunate, many of the rude flints being found, and implements of the accepted types, in association with a spread of deep ochreous flint.

This led to a complete survey of the district, so that the chalk plateau was rigorously searched and many new localities added. I may mention those positions on each of which rude specimens have been found:-Terry's Lodge, Peckham Wood, Ash, South Ash (two patches), West Yoke, Sparks Field, Kingsdown, Cotman's Ash, Wrotham Hill, The Vigo, Birches, Wick Farm, and Bower Lane on the east of the Darent. Morant's Court Hill, Polhill Plain, the bed of coarse gravel lying above Eynesford on the west, and more recently on Telegraph Hill, Swanscombe.

Most of these implements have been found on the surface, with a few exceptions, which are laid out separately for inspection.

The first was thrown out from a post hole on the Kingsdown Plain, another from a hole dug two feet deep in which to plant damson trees at Parsonage Farm, the third from a pond bank deep down at Ash, and the fourth from a spread of deep red clay at The Vigo.

The West Yoke and South Ash patches, on which I first worked with a will, proved remarkably prolific, yielding both the rude and the accepted types of implements.

One from the former locality is deserving of careful attention. 
It is of the spear-head type, of a deep red colour, and the angles of work so much worn it seems to have been derived from some tormer resting-place and to have suffered in transport.

The accumulation of so many of these rude examples impressed me.

Though many may possibly be classed as merely field tools "picked and used for chopping and hammering in the same way as one sometimes picks up and uses a pebble now-a-days," still there are scores of others evidently selected and fashioned in such a way that I felt justified in separating them into groups. Feeling confident that they do bear the impress of man, and possibly represent his first essays in handiwork (certainly in the Thames Basin), I have classified them as represented in the accompanying sheet :-

Provisionally I have them grouped thus:-

1. Crook point tool, Fig. 10, Plate XX.

2. Single curve scraper, Fig. 1, Plate XIX.

3. Double curved scraper, Fig. 8, Plate XX.

4. Combination tool, Fig. 2, Plate XIX.

5. Split pebble group, with work on side, Fig. 5, Plate XIX.

6. Semi-circular tool, Fig. 3, Plate XIX.

7. Drawshave or hollow scraper, Figs. 4, 5, Plate XX.

8. Tool with work all round, Fig. 4, Plate XIX.

1. Crook point.-The crook point is common to all patches, and stones were so selected that but a very little manipulation served to make an effective tool. No. 1 of this group was found long since and treasured. From the patina upon it I felt confident it was of palæolithic age, but no others of a like shape were lighted on for many months.

A specialist to whom it was shown was much impressed with its peculiar shape, and said it might have been used as a field tool and cast aside, but the finding of many more convinced me that a selection as to shape had been made, and it had been used for some special purpose.

2. Single curve scraper or pointed tool.-These evidently were common tools, as so many of this form are to be found, some very small and others of a much larger size, but as a rule trirnmed on one side only.

In some instances these are so worked that a point may have been the desired end, but the majority seem to me so operated upon as if for the purpose of a single side-scraper.

3. Double curved scrapers.-Many of this form are found and seem to have been a handy useful tool, possibly used in scraping round surfaces.

Several indicate long-continued use from the wear, and may have been prized tools. 
4. Combination tools.-So named from the fact that some three tools are combined in one.

The point for a definite use, the hollow scraper or drawshave, whilst the butt end is so trimmed as to form a broad end scraper.

The stones so shaped evidently were selected, and by thinking it out our early stone-workers so operated on the flint that a very handy tool was secured, or I may say three tools in one.

5. Split pebble group, with work on one side.-Of these many examples are shown. At first doubt existed, and I felt reluctant to place them in evidence, but many careful observations and the finding some on each patch seemed to justify the group being removed from the suspense account and placed as a distinct class.

I feel confident from my later observations that split pebbles had been sought, for and when found, by trimming on one side, useful tools for cutting or chipping were secured.

6. Semi-circular.- These are not quite so common, but enough were found to warrant me in believing that flints of this shape had been selected, and all being worked in a definite manner, may have had some special use.

7. Drawshaves or hollow scrapers.-This group seem to be the most common of all, found everywhere and abundant in every patch.

Some much worn by use and possibly highly prized tools; others as if only worked up to supply the need of the time and perhaps cast away and discarded. Still they are so numerous one cannot but look upon them as ordinary handy tools and useful for various purposes.

8. Tools with work all round.-These tools bearing work on all sides are perhaps more convincing to sceptics than many preceding groups, and it will be seen strikingly resemble each other in form.

I may add that those more convincing examples were not immediately found on my instituting a regular search, but the ordinary rude choppers were first observed many years since, but the work was so rude and indefinite it was only by carefully amassing scores of similar examples that one felt justified in putting in evidence.

These rude choppers are not grouped, as their form presents such infinite variety, but the work upon the sharper edge is sufficient to warrant the feeling that a human purpose is visible in the working.

In completing this work each specimen has been carefully examined by a hand lens before being sketched in my catalogue, 
and though hundreds of others bearing some work are in my possession, care has been taken to include only those that may be truly deemed to have been worked intentionally and for a definite purpose.

The total number of these rude examples of man's handiwork sketched and catalogued exceeds 600 .

If these are accepted as rude beginnings and showing a human purpose in them, the striving for something better which in due time followed, then I. am content, and I beg to lay before the Institute the results of many years' observations and the harvest of later years' careful and persistent search.

\section{Notes by De Barri Crawshay, Esq.}

Professor Prestwich has asked me to write a few notes as to the work that I have done upon the Western Chalk Platean comprised in his paper. There remains but little for me to say, but at his request I append a few details of the places and their productions, that you may have an accurate total to date of the large volume of evidence of the earliest traces of man in Britain. ${ }^{1}$

List of Specimens from the Chalk Plateau West to June 1st, 1891 "Crawshay Collection."

\begin{tabular}{|c|c|c|c|c|c|c|c|}
\hline $\begin{array}{c}\text { Date of } \\
\text { Discovery. }\end{array}$ & \multicolumn{2}{|l|}{ Name of Locality. } & O.D. I.evel. & $\begin{array}{c}\text { Various } \\
\text { Implements. }\end{array}$ & $\begin{array}{l}\text { Scraper } \\
\text { Flakes. }\end{array}$ & $\begin{array}{l}\text { Simple } \\
\text { Flakes. }\end{array}$ & Total. \\
\hline $15 / 1 / 91$ & Botley Hill.... & & \multirow{16}{*}{$\begin{array}{c}875 \\
864 \\
820 \\
780 \\
790 \\
750-790 \\
700 \\
485 \\
475 \\
495 \\
475 \\
500 \\
530 \\
400 \\
430\end{array}$} & 5 & . & $\ldots$ & $\therefore$ \\
\hline $28 / 4 / 90$ & Titsey Hill .... & $\ldots$ & & 11 & $\ldots$ & $\ldots$ & 11 \\
\hline 151,91 & Tatstield Firs & .... & & 3 & $\ldots$. & .... & 3 \\
\hline $15 / 1 / 91$ & Park Wood.... & .... & & 1 & $\ldots$ & $\ldots$. & 1 \\
\hline $29 / 10 / 89$ & Ivy Cottage.... & .... & & 13 & $\ldots$. & $\ldots$ & 13 \\
\hline $1 / 4 / 89$ & Betsoms Ḧill & .... & & 21 & 2 & $\ldots$ & $2: 3$ \\
\hline $1 / 4 / 89$ & Morants Hill & .... & & 1 & $\ldots$ & $\ldots$. & 1 \\
\hline $15 / 3 / 89$ & Norstead $\ldots .$. & .... & & 51 & 1 & 1 & 5.1 \\
\hline $15 / 3 / 89$ & Norstead, East & .... & & & .... & 1 & 1 \\
\hline $12 / 11 / 88$ & Halstead $\quad . .$. & .... & & 19 & 2 & 15 & 36 \\
\hline $15 / 3 / 90$ & Hewetts .... & $\ldots$. & & 2 & 1 & .... & 3 \\
\hline $25 / 4 / 91$ & Colegates $\quad . .$. & .... & & 1 & & $\ldots$. & 1 \\
\hline $9 / 7 / 89$ & Jerkins Wood & $\ldots$. & & 35 & 2 & 3 & 40 \\
\hline $15 ; 3 / 89$ & Farthing Street & .... & & 5 & .... & 1 & 6 \\
\hline \multirow[t]{2}{*}{$27 / 6 / 90$} & \multirow[t]{2}{*}{ Oldwan Wood } & \multirow[t]{2}{*}{.... } & & 1 & .... & .... & 1 \\
\hline & & & & 169 & 8 & 21 & 198 \\
\hline
\end{tabular}

1 I would separate palæolithic implements into two divisions, the usual term, "palæoliths," seeming to me irsufficient, venturing upon a new word "palæotalith," to designate the ruder and less uniformly shaped form of implement, as compared to the implement which has been flaked as is usual (referred 10 on 